\section{A Lesson From}

\section{"Organizational Developments}

\section{and Program Adjustments}

\section{in the Canadian}

\section{Forestry Service"}

Within the past year, the major event affecting the profession of forestry in Canada has been the upheaval in the Canadian Forestry Service, announced last December. The lay-offs, transfers, and related changes have attracted only scant notice and less discussion in the general and trade press. By airing some of the substantive and procedural questions involved, the April issue of the Forestry Chronicle therefore performed a notable service to all C.I.F. mebers, not merely those employed by the Canadian Forestry Service.

When a mature and experienced professional in the C.F.S. submits criticism of his minister and other superiors for anonymous publication, he is plainly distressed and frustrated. Similarly, Dr. Prebble's response conveys much useful information, together with an unmistakable tone of anguish and frustration. In effect, each writer regards the other as having behaved less considerately than the circumstances required.

It is neither feasible nor wise for an uninformed outsider to comment on the substance of the decisions that Dr. Prebble describes and defends in his article. Given the same peculiar situation (including the special constraints of prior commitments, collective bargaining practices, and government fiscal policy) it is even conceivable that a group of C.F.S. staff might have arrived at a similar set of decisions. * It is also true that the "friendly colleague" who tries to share his "insights" into others' quarrels may find these insights at best unwelcome and at worst ill-founded. Nonetheless, this seems a time when it is worth rising above principle, by recognizing one lesson of this unhappy affair.

Among the reasons for considering the Federal government as "a poor employer", the anonymous correspondent included the charge that "individuals laid off or transferred were notified by form letter. ... Apparently senior Forestry Service officials and their subordinates [emphasis added] did not have the courtesy or the intestinal fortitude to personally tell 220 individuals of their lay-off or transfer."

In replying to this allegation, Dr. Prebble wrote stiffly and correctly: "I am not aware of any discourtesy or lack of 'intestinal fortitude' in proceeding with this unpleasant task. There are Treasury Board and Public Service Commission guidelines for such processes... Some 3,300 letters of differing substance had to be delivered to individual members of the Forestry Service within a period of about one day, and these had to be form-letter type. Every one bore my signature and was the result of individual decision. It was pat-

\footnotetext{
* Some of the published criticism of the cut-backs has amounted to little more than the following false syllogism: The Canadian Forestry Service has developed a program of forestry research; forests are very important to Canada; therefore, the C.F.S. research program should not be cur-
} tailed. ently impossible to write a personal letter to each of the surplus-listed employees, as the author of the preceding article must surely know."

With the two quotations set together it is easy to see one of the things that went wrong: the C.F.S. researcher (who was not "surplus-listed") had not conveyed the idea that the required form letters could have been personally handed over by supervisors, with appropriate words of explanation or comment. The absence of such personal involvement led to predictably angry feelings not only among those who were fired, but also among many of those who were retained but still felt badly slighted.

Months after the event and after the C.F.S. administrators had received "many individual and joint reactions" to the decisions announced in December, Dr. Prebble's reply showed no awareness of the need for personal communication.

In our age of magic communication facilities, we still suffer unnecessarily from our inabilities to meet the needs for communication among individuals in many groups, large and small, governmental and corporate. Experiences of this kind stimulate the growth of professional unionism, when the individual professional feels he can no longer expect to be dealt with individually, even in a matter as crucial to his selfesteem as his job and its direction.

To recognize our own problems in the experience of others is no easier and no less important than it has ever been. One lesson from this painful experience in our own profession is that a willingness to tell people unpleasant facts may sometimes avert the greater pain that follows a strict adherence to impersonal rules of procedure.

\section{H. I. Winer \\ Associate Editor - Logging}

